\title{
A Message from the President
}

By FRANK ROY, Saskatoon

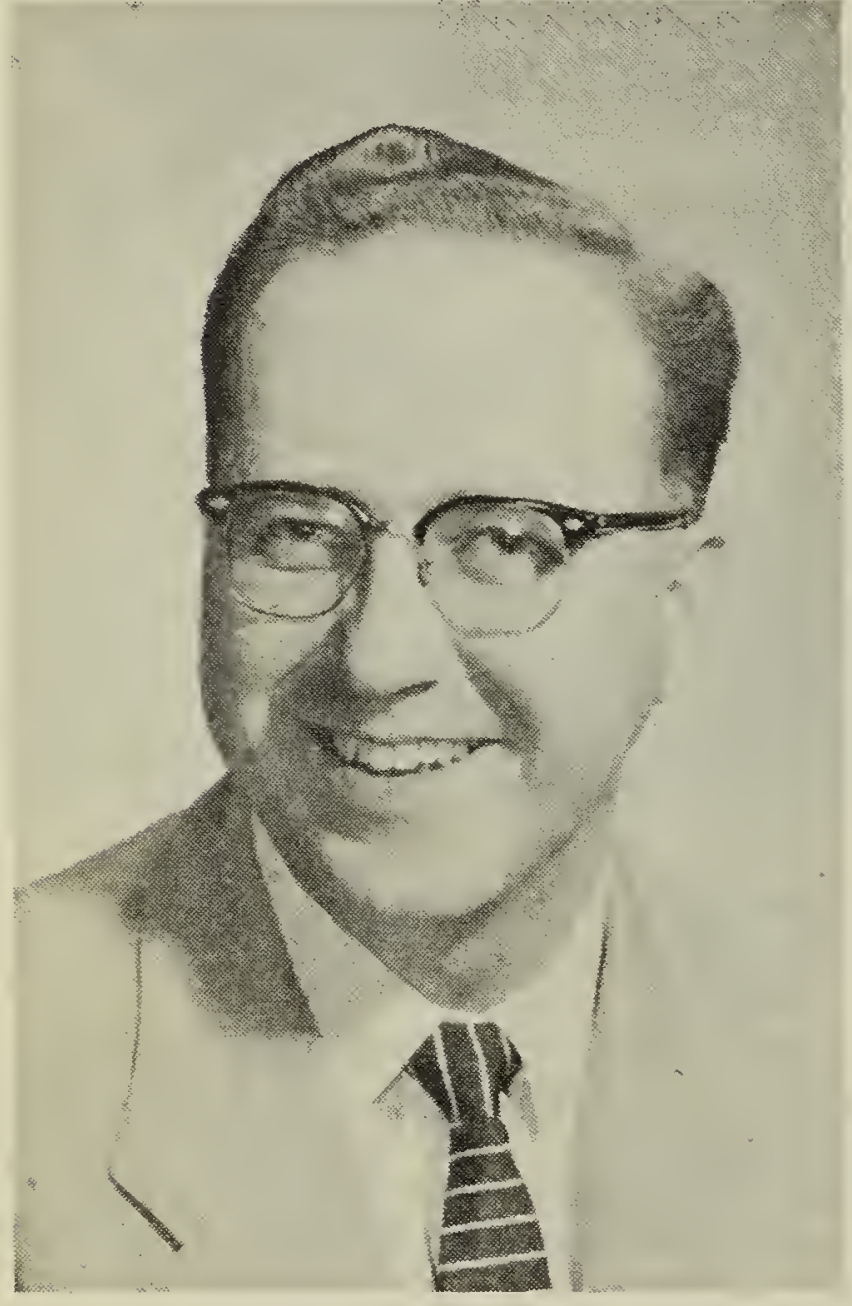

Boys born on the prairie are indeed close to Nature. They know the warmth of a winter sun on the southern side of the oatstack, the inquisitive squeaking of the gopher, the first furry buds of the crocus, and the clamorous honks of Canada geese as they fly over golden stubble fields. They have felt moist earth beneath their bare feet as they planted potatoes; they have lain on their backs in a lily-spangled meadow watching a red-tail swing in giant arcs a mile overhead; they have trudged home from school, knee-deep in snow, awed by the pink fullness of the December moon. But prairie boys are frequently uncommunicative; they regard the outdoors with a silent, unspoken affection. They have learned to enjoy Nature in solitude, often because there is no one else with whom they can share that experience.

I was such a boy, fifteen years ago, when I first heard of Mrs. Priestly. The Western Producer an- nounced that a Yorkton woman ha just published the first issue of little magazine entitled "The Blu Jay." She was trying to conta nature-lovers from all over the pro vince. How wonderful - there wer others, and in this province, interes ed in wildlife! I subscribed immed ately, and thus began my acquair tance with Mrs. Priestly and he young protege, a boy named Stua: Houston.

How things have changed sind 1942. The mimeographed bullet: with the hand-coloured cover has bo come a compact, well illustrate journal, respected across the contin ent. The total of 80 initial subscribe has swelled to 2,500. Mrs. Priestl the founder, is dead, but her wo lives on in the pages of the Blue $\mathrm{J}$ : and in the Natural History Societiacross the province.

The Provincial Society has accor plished a great deal since its fou dation in 1949. Its members ha assisted in co-operative bird mi ration studies, added new species the plant, bird and mammal lists $f$ the province, led in efforts to promo conservation of our wildlife resourc urged the government to build Natural History Museum, organiz summer expeditions to various are cf the province-to name but a ff activities. The Society musit contin to face up to its growing respo sibilities. Above all, we should wo constantly to support the editor a staff of the Blue Jay by contributi articles and observations, and bringing the magazine to the attenti of an ever-widening circle of reade

We are happy that Saskatoon $r$ been chosen as the site for $n t$ year's annual meeting. We feel st that 1958 will be a year when me: bers from the northern half of 1 province will be able to attend br the summer outing at Emma Le and fall meeting in Saskatoon greater numbers. I know that provincial organization will be a to count on the loyal support of 1 Saskatoon Natural History Soci and the staff of the University Saskatchewan in our preparations the meeting next October. 